\title{
Anauxetic dysplasia: A rare clinical entity
}

\author{
Özlem Akgün-Doğan, Pelin Özlem Şimsek-Kiper, Gülen Eda Utine, Koray Boduroğlu \\ Division of Pediatric Genetics, Department of Pediatrics, Hacettepe University Faculty of Medicine, Ankara, Turkey. \\ E-mail: ozlem.akgun@hacettepe.edu.tr \\ Received: 23th April 2017, Accepted: 31st May 2017
}

\begin{abstract}
SUMMARY: Akgün-Doğan Ö, Şimsek-Kiper PÖ, Utine GE, Boduroğlu K. Anauxetic dysplasia: A rare clinical entity. Turk J Pediatr 2018; 60: 89-93.

Cartilage hair hypoplasia and anauxetic dysplasia spectrum constitute a group of autosomal recessive disorders characterized by variable extent of metaphyseal to spondylometaepiphyseal involvement and various additional clinical features. Within this group, anauxetic dysplasia represents the severe end of the skeletal spectrum. However, extraskeletal features including immunodeficiency, hematological abnormalities, and hair hypoplasia are absent, despite the severe skeletal involvement. This disorder is caused by mutations in the gene encoding ribonuclease mitochondrial RNA-processing complex. We herein report on a patient with anauxetic dysplasia, who presented with severe roto-scoliosis and skeletal findings requiring surgical intervention, and in whom a homozygous RMRP mutation was detected.
\end{abstract}

Key words: anauxetic dysplasia, metaphyseal dysplasia, autosomal recessive, scoliosis.

Anauxetic dysplasia (AD, MIM 607095) is one form of spondylometaepiphyseal dysplasia with features distinctive from others. The name 'anauxetic dysplasia' (from the Greek term for 'not growing' or 'not permitting growth') was suggested on the basis of extreme short stature resulting from a severe pre- and postnatal disturbance of skeletal growth and differentiation. ${ }^{1} \mathrm{AD}$ and cartilagehair hypoplasia ( $\mathrm{CHH}$, MIM 250250) display together a spectrum and they constitute a continuum ranging from short stature without hypotrichosis and with only radiographic evidence of metaphyseal dysplasia (metaphyseal dysplasia without hypotrichosis, MIM 250460) to severely deforming short stature with metaphyseal, epiphyseal, and vertebral dysplasia, namely AD. The most commonly associated phenotype is $\mathrm{CHH}$ with short-limbed short stature and variable hair hypoplasia. Other phenotypes including AD are quite rare. To our knowledge, only seven patients from four families with AD have been reported in the literature so far. $^{2}$

Differential diagnosis of $\mathrm{AD}$ includes other metaphyseal dysplasias such as Schmid dysplasia, Jansen dysplasia, ShwachmanDiamond syndrome and Omenn syndrome. The clinical diagnosis is made based on clinical history, physical and radiographic findings. There is marked phenotypic variability within $\mathrm{CHH}-\mathrm{AD}$ spectrum disorders. ${ }^{1}$ While $\mathrm{AD}$ is relatively a bone-restricted disorder, $\mathrm{CHH}$ is a more pleiotropic metaphyseal chondrodysplasia characterized by common extraskeletal findings including hypoplastic hair, defective immunity, impaired spermatogenesis, deficient erythropoiesis and increased risk of malignancies. , $^{3,4}$

Homozygous or compound heterozygous mutations in ribonuclease mitochondrial RNA-processing complex gene (RMRP, MIM 157660) cause CHH-AD spectrum disorders. Recently, POP1 (MIM 602486), mutations have also been reported in patients with a CHH-like phenotype. ${ }^{5,6}$ While RMRP encodes the untranslated RNA subunit of RNase MRP, POP1 encodes a core component of the RNase mitochondrial RNA processing ${ }^{6}$. Herein, we report on a patient with $A D$ caused by homozygous RMRP mutations, who presented with severe short stature and scoliosis requiring surgical intervention.

\section{Case Report}

An 11-year-old female patient was referred to our clinic for severe short stature. She was born 
at term as the second live-born child of her consanguineous parents (first cousins) with a birth weight of $3,500 \mathrm{~g}$ ( $50^{\text {th }}$ centile), following an uneventful pregnancy. Her birth length and head circumference were not noted but short stature with short extremities was noticed in early childhood. Her motor and intellectual developmental milestones were all normal. On physical examination, her height was 82 $\mathrm{cm}$ (-8.8 SD, standard deviation), weight was $21.5 \mathrm{~kg}(-3.3 \mathrm{SD})$, head circumference was $52 \mathrm{~cm}$ (mean) and arm span was $91 \mathrm{~cm}$. She had short-limbed short stature. She also had a short neck, a barrel chest, severe scoliosis, and lumbar hyperlordosis. Limited elbow extension, ligamentous laxity with short, pudgy hands and feet were also noted (Fig. 1). She did not have dental abnormalities, however, she had fine hair, eyebrows and eyelashes. She did not have a history of recurrent infections.
Radiographic examinations revealed shortening and metaphyseal dysplasia of the tubular bones, with metaphyseal irregularities specifically more severe in the knee region, less than normal craniocaudal widening of the interpeduncular distance in lumbar spine, small femoral epiphyses with hypoplastic femoral necks and widened proximal femoral metaphyses, shallow acetabula, hypoplastic iliac bodies, severe scoliosis and hyperlordosis (Fig.1). Laboratory studies including quantitative immunoglobulins, lymphocyte subsets, and blastic transformation were all normal.

On clinical diagnosis of anauxetic dysplasia, molecular analysis was planned. Appropriate informed consent was obtained from the patient and her family. Molecular analysis in peripheral blood lymphocytes of the patient revealed homozygous pathogenic mutation g.[92_93insA] in RMRP, confirming the clinical

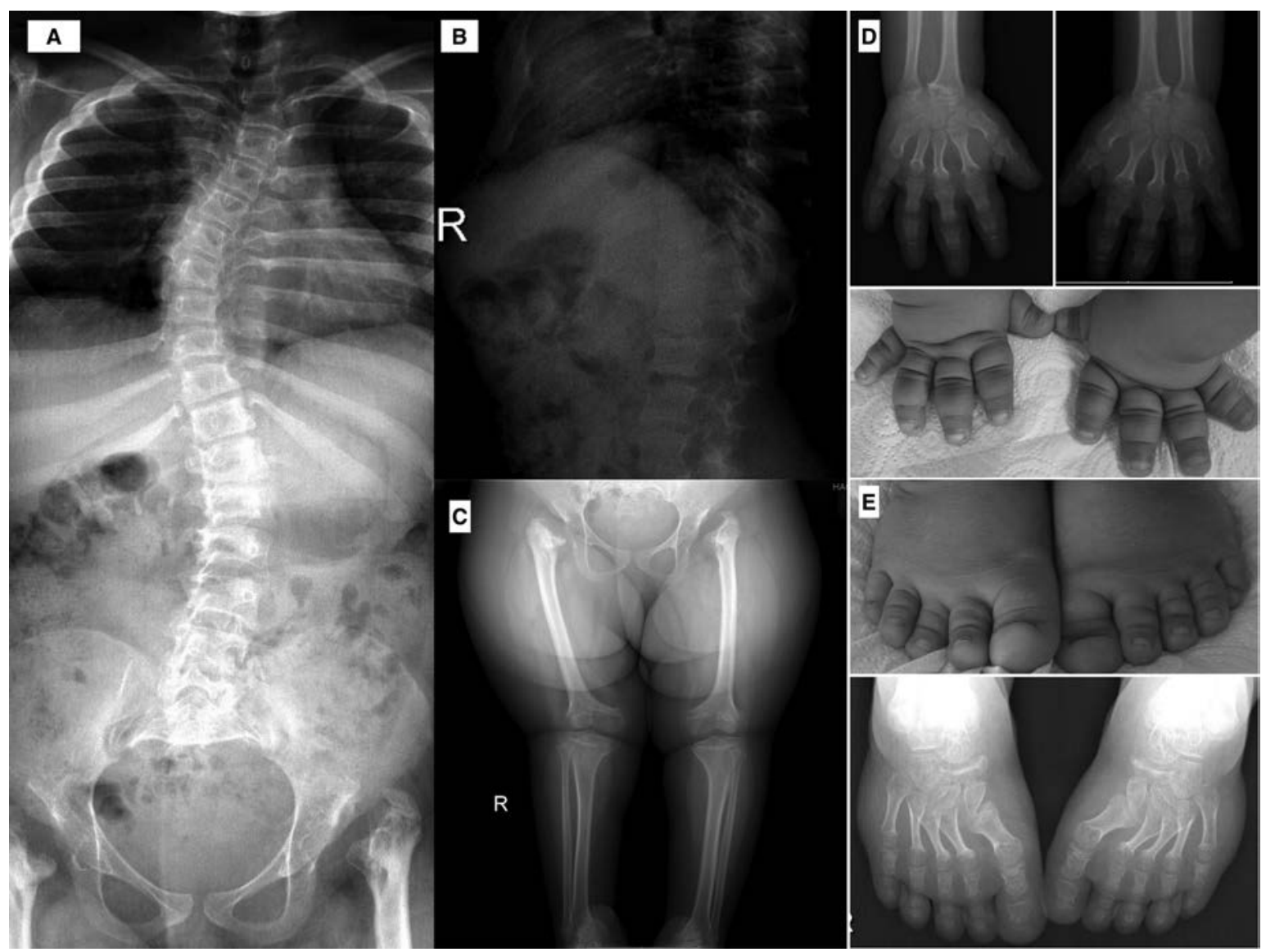

Fig. 1. Clinical and radiographic features of the patient. Note the severe scoliosis and lumbar hyperlordosis, less than normal craniocaudal widening of interpeduncular distance in the lumbar spine, irregular vertebral end plates, columnar and posteriorly scallopped vertebral bodies $(\mathrm{a}, \mathrm{b})$, hypoplastic proximal and distal femoral epiphyses with hypoplastic femoral necks and widened metaphyses, shallow acetabula, hypoplastic iliac bodies (c), and short, pudgy hands and feet, brachydactyly, and metaphyseal irregularities in tubular bones of hand and feet (d, e). 
Table I. Clinical and Molecular Findings In Previously Reported AD Patients and The Present Case.

\begin{tabular}{|c|c|c|c|c|c|c|c|c|c|c|c|}
\hline \multirow{3}{*}{ References } & \multicolumn{8}{|c|}{$R M R P$ related } & \multicolumn{3}{|c|}{ POP1 related } \\
\hline & \multicolumn{3}{|c|}{ Menger et al. (7) } & \multicolumn{2}{|c|}{ Horn et al. (1) } & \multicolumn{2}{|c|}{ Thiel et al. $(2,9)$} & \multirow{2}{*}{$\frac{\text { Present report }}{\text { Present }}$} & \multirow{2}{*}{ 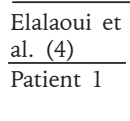 } & \multicolumn{2}{|c|}{$\begin{array}{l}\text { Glazov et } \\
\text { al. (3) }\end{array}$} \\
\hline & $\begin{array}{l}\text { Patient } \\
1\end{array}$ & $\begin{array}{l}\text { Patient } \\
2\end{array}$ & Patient 3 & Patient 1 & Patient 2 & Patient 1 & Patient 2 & & & $\begin{array}{l}\text { Patient } \\
1 \\
\end{array}$ & $2^{\text {Patient }}$ \\
\hline Mutation & $\begin{array}{l}\text { g.111_1 } \\
\text { ACGTA }\end{array}$ & $\begin{array}{l}\text { 112ins } \\
\text { AGACAT }\end{array}$ & TCCT & $\begin{array}{l}\text { g.90_91AG } \\
\text { and g.14A }\end{array}$ & $\begin{array}{l}\mathrm{G}>\mathrm{GC} \\
\mathrm{a}>\mathrm{T}\end{array}$ & $\begin{array}{l}\text { g.90_91AG }>\text { GC } \\
\text { and g.245C }>\text { G }\end{array}$ & $\begin{array}{l}\text { g.254_263de } \\
\text { CTCAGCGCGG }\end{array}$ & g.92_93insA & c. $1744 \mathrm{C}>\mathrm{T}$ & $\begin{array}{l}\text { c. } 1573 \mathrm{C} \\
\mathrm{c.} 1748 \mathrm{C}\end{array}$ & $\begin{array}{l}>T \text { and } \\
G>A\end{array}$ \\
\hline $\begin{array}{l}\text { Country of } \\
\text { origin }\end{array}$ & Jordan & Jordan & Jordan & Germany & Germany & Germany & $\begin{array}{l}\text { and } \mathrm{N} / \mathrm{A} \cdot 195 \mathrm{C}>\mathrm{T} \\
\end{array}$ & Turkey & Morocco & $\mathrm{N} / \mathrm{A}$ & $\mathrm{N} / \mathrm{A}$ \\
\hline Family history & + & + & + & + & + & - & - & - & - & + & + \\
\hline Gender & $\mathrm{F}$ & $\mathrm{M}$ & M & M & M & N/A & F & M & M & N/A & N/A \\
\hline $\begin{array}{l}\text { Age at } \\
\text { diagnosis }\end{array}$ & 19 & 7 & 3 & 3 & 11 & 7 & 11 & 11 & 5 & N/A & N/A \\
\hline Consanguinity & + & + & + & - & - & - & - & + & + & - & - \\
\hline \multicolumn{12}{|l|}{ Growth } \\
\hline Birth length & $\mathrm{N} / \mathrm{A}$ & N/A & $\mathrm{N} / \mathrm{A}$ & $\begin{array}{l}43 \mathrm{~cm} \\
(-3.4 \mathrm{SD})\end{array}$ & $\begin{array}{l}46 \mathrm{~cm} \\
(-2.1 \mathrm{SD})\end{array}$ & $\begin{array}{l}37 \mathrm{~cm} \\
(-4.7 \mathrm{SD})\end{array}$ & $\begin{array}{l}39 \mathrm{~cm} \\
(-5 \mathrm{SD})\end{array}$ & N/A & $\begin{array}{l}41 \mathrm{~cm} \\
(-3 \mathrm{SD})\end{array}$ & $\mathrm{N} / \mathrm{A}$ & N/A \\
\hline $\begin{array}{l}\text { Height at } \\
\text { admission }\end{array}$ & $85 \mathrm{~cm}$ & $69 \mathrm{~cm}$ & $66 \mathrm{~cm}$ & $\begin{array}{l}62 \mathrm{~cm} \\
(-9.4 \mathrm{SD})\end{array}$ & $\begin{array}{l}74 \mathrm{~cm} \\
(-11.8\end{array}$ & $\begin{array}{l}53 \mathrm{~cm} \\
(-13.2 \mathrm{SD})\end{array}$ & $\begin{array}{l}83 \mathrm{~cm} \\
(-8 \mathrm{SD})\end{array}$ & $82 \mathrm{~cm}$ & $\begin{array}{l}78 \mathrm{~cm} \\
(-3 \mathrm{SD})\end{array}$ & N/A & N/A \\
\hline $\begin{array}{l}\text { Facial } \\
\text { dysmorphism }\end{array}$ & & & & & & & & & & & \\
\hline $\begin{array}{l}\text { Middle face } \\
\text { hypoplasia }\end{array}$ & + & + & + & + & + & N/A & + & + & + & N/A & N/A \\
\hline Hypertelorism & + & + & + & + & + & N/A & + & + & N/A & $\mathrm{N} / \mathrm{A}$ & N/A \\
\hline Short neck & + & + & + & + & + & $\mathrm{N} / \mathrm{A}$ & + & + & $\mathrm{N} / \mathrm{A}$ & $\mathrm{N} / \mathrm{A}$ & N/A \\
\hline Hypodontia & + & - & - & + & + & N/A & - & - & N/A & $\mathrm{N} / \mathrm{A}$ & N/A \\
\hline \multicolumn{12}{|l|}{$\begin{array}{l}\text { Skeletal } \\
\text { findings }\end{array}$} \\
\hline $\begin{array}{l}\text { Rhizomelic } \\
\text { shortening }\end{array}$ & + & + & + & + & + & + & + & + & + & N/A & N/A \\
\hline $\begin{array}{l}\text { Metaphyseal } \\
\text { flaring \& } \\
\text { irregularity }\end{array}$ & + & + & + & + & + & + & + & + & + & + & + \\
\hline $\begin{array}{l}\text { Small } \\
\text { epiphyses }\end{array}$ & + & + & + & + & + & + & + & + & + & + & + \\
\hline Platyspondyly & + & + & + & + & + & + & - & + & + & + & + \\
\hline $\begin{array}{l}\text { Atlanto-axial } \\
\text { subluxation }\end{array}$ & - & - & - & + & + & + & - & - & N/A & + & + \\
\hline Scoliosis & + & - & - & - & - & - & + & + & + & N/A & N/A \\
\hline $\begin{array}{l}\text { Hypolastic } \\
\text { femoral necks }\end{array}$ & + & + & + & + & + & + & + & + & + & + & + \\
\hline $\begin{array}{l}\text { Hypoplastic } \\
\text { ilia }\end{array}$ & + & + & + & + & + & + & + & + & $\mathrm{N} / \mathrm{A}$ & + & + \\
\hline $\begin{array}{l}\text { Shortening } \\
\text { of acetabular } \\
\text { roof }\end{array}$ & + & + & + & + & + & + & + & + & + & + & + \\
\hline Brachydactyly & + & + & + & + & + & + & + & + & + & + & + \\
\hline $\begin{array}{l}\text { Delayed carpal } \\
\text { bone age } \\
\text { Other findings }\end{array}$ & $1+$ & + & + & + & + & N/A & N/A & + & + & N/A & N/A \\
\hline $\begin{array}{l}\text { Developmental } \\
\text { delay }\end{array}$ & $1+$ & + & + & + & + & + & - & - & - & $\mathrm{N} / \mathrm{A}$ & N/A \\
\hline $\begin{array}{l}\text { Intellectual } \\
\text { disability }\end{array}$ & + & + & + & + & + & + & - & - & - & N/A & $\mathrm{N} / \mathrm{A}$ \\
\hline $\begin{array}{l}\text { Immune } \\
\text { deficiency }\end{array}$ & N/A & N/A & N/A & N/A & N/A & N/A & N/A & - & N/A & $\mathrm{N} / \mathrm{A}$ & N/A \\
\hline $\begin{array}{l}\text { Cervical cord } \\
\text { compression }\end{array}$ & - & - & - & + & - & + & - & - & N/A & N/A & N/A \\
\hline
\end{tabular}

F: female; M: male; N/A: not available; SD: standard deviation 
diagnosis. Unaffected parents and the healthy elder sister were heterozygous for the same mutation. An informed consent was received from the family for publication.

\section{Discussion}

In 1996 Menger et al. ${ }^{7}$ reported three affected siblings with extreme short stature, rhizomelic shortening of the limbs with stubby hands and feet, lumbar hyperlordosis, kyphoscoliosis, and limited extension of the elbows. Radiographs revealed severely short tubular bones with irregular metaphyses and deformed small epiphyses, hypoplastic iliac bones, slanting acetabular roofs, short, broad phalanges and hypoplastic terminal phalanges. The authors proposed this entity as a new form of distinct autosomal recessive skeletal dysplasia. ${ }^{7}$ Then, in 2001 Horn et al. ${ }^{1}$ reported two brothers with severe disproportionate rhizomelic short stature, brachydactyly and dysmorphic facial features. The authors believed that these two brothers had actually the same clinical condition as the one described by Menger et al. ${ }^{7}$, however, there were some clinical differences. One of the siblings had small teeth while the other one had normal shaped teeth but absence of some of the permanent teeth. In addition, one of the siblings developed respiratory insufficiency and quadriplegia attributed to cervical cord compression and atlantoaxial subluxation. The authors suggested naming this clinical and skeletal phenotype as "anauxetic dysplasia" on the basis of the extreme short stature resulting from severe pre- and post-natal disturbance of the skeletal growth and maturation.

In 2005 and 2007, Thiel et al.8,9, reported two other patients with extreme short stature, from two unrelated families. Clinical and radiographic findings were consistent with those of the previously reported patients. Progressive spasticity due to cervical compression was present in the first patient, as previously described by Horn et al., ${ }^{1}$ however, scoliosis was noted in the second patient as an additional feature.

The present patient was evaluated for severe disproportionate short stature with short limbs, brachydactyly, limited extension of the elbow, metacarpophalangeal joint laxity and hyperlordosis. These findings were consistent with the previously reported patients within CHH-AD spectrum (Table I). However, presence of severe rotoscoliosis requiring surgical intervention was striking. Although she had severe rotoscoliosis she did not have any neurological findings including cervical atlantoaxial instability and cord compression.

Homozygous/compound heterozygous $R M R P$ mutations cause CHH-AD spectrum disorders. Recently POP1 mutations have also been reported in patients with a $\mathrm{CHH}$ like phenotype $^{5,6}$. More than 90 RMRP mutations have been identified in this spectrum so far $^{2}$. Homozygous RMRP mutations have been reported to be associated with a clinically more severe phenotype compared to compound heterozygous RMRP mutations ${ }^{2}$. Regarding AD, only six mutations have been described so far. ${ }^{2}$ The present patient was homozygous for a previously reported g.(92_93insA) mutation in $R M R P .^{2}$ This mutation was previously shown to cause an alteration in functional rRNA cleavage in RNAse MRP complex and has been implicated in AD spectrum, in which bone dysplasia is the prominent feature without immunological findings. ${ }^{9}$ The present patient had a more severe skeletal phenotype and had none of the extraskeletal findings including immunodeficiency, hematological abnormalities, and hair hypoplasia, consistent with the AD phenotype seen in mutations affecting rRNA cleavage .

In conclusion, $\mathrm{CHH}-\mathrm{AD}$ spectrum constitutes a group of skeletal dysplasias characterized by variable metaphyseal dysplasia with a highly pleiotropic phenotype. In this group, $A D$ is extremely rare and represents the severe end of the skeletal spectrum. RMRP mutations are responsible from the disorder. Given the clinical and radiographical variability in this spectrum, interpretation of clinical and molecular findings is important for appropriate diagnosis, management and genetic counseling.

\section{Acknowledgement}

We would like to thank to our patient and her family for their collaboration. We would also like to thank to Prof. Andrea Superti-Furga and Prof. Luisa Bonafe from the University Hospital of Lausanne, Lausanne, Switzerland for the molecular genetic analysis of our patient. 


\section{REFERENCES}

1. Horn D, Rupprecht E, Kunze J, Spranger J. Anauxetic dysplasia, a spondylometaepiphyseal dysplasia with extreme dwarfism. J Med Genet 2001; 38: 262- 265.

2. Thiel CT, Rauch A. The molecular basis of the cartilagehair hypoplasia-anauxetic dysplasia spectrum. Best Pract Res Clin Endocrinol Metab 2011; 25: 131-142.

3. McKusick VA, Eldridge R, Hostetler JA, Ruangwit U, Egeland JA. Dwarfism in the Amish. II. Cartilage-hair hypoplasia. Bull Johns Hopkins Hosp 1965; 116: 285326.

4. Makitie O, Kaitila I, Rintala R. Hirschsprung disease associated with severe cartilage-hair hypoplasia. J Pediatr 2001; 138: 929-931.

5. Glazov EA, Zankl A, Donskoi M, et al. Whole-exome re-sequencing in a family quartet identifies POP1 mutations as the cause of a novel skeletal dysplasia. PLoS Genet 2011; 7: e1002027.
6. Elalaoui SC, Laarabi FZ, Mansouri M, Mrani NA, Nishimura G, Sefiani A. Further evidence of POP1 mutations as the cause of anauxetic dysplasia. Am J Med Genet A 2016; 170: 2462-2465.

7. Menger H, Mundlos S, Becker K, Spranger J, Zabel B. An unknown spondylo-meta-epiphyseal dysplasia in sibs with extreme short stature. Am J Med Genet 1996; 63: 80-83.

8. Thiel CT, Horn D, Zabel B, et al. Severely incapacitating mutations in patients with extreme short stature identify RNA-processing endoribonuclease RMRP as an essential cell growth regulator. Am J Hum Genet 2005; 77: 795-806.

9. Thiel CT, Mortier G, Kaitila I, Reis A, Rauch A. Type and level of RMRP functional impairment predicts phenotype in the cartilage hair hypoplasia-anauxetic dysplasia spectrum. Am J Hum Genet 2007; 81: 519529. 